\title{
Weed Interference and Growth Performances in Soybean (Glycine max (L.) Merr.), as affected by Weed Density and Types of Weed
}

\author{
Sawatdikarn Sanit ${ }^{1}$
}

\author{
${ }^{1}$ Department of Applied Science, Faculty of Science and Technology, Phranakhon Si Ayutthaya Rajabhat \\ University, Phranakhon Si Ayutthaya, Thailand
}

\begin{abstract}
The aim of this study was to evaluate of the density for four weeds on growth inhibition against soybean (Glycine max) (Chiang Mai 2 variety). The experiment were interfered with four weeds namely wild poinsettia (Euphorbia heterophylla), eclipta (Eclipta prostrata), slender amaranth (Amaranthus viridis) and spiny amaranth (Amaranthus spinosus) against soybean $(G . \mathrm{max})$. The number of four weeds interfered with soybean planting divided into five treatments; 0 (control treatment) 4812 and 16 plants $/ \mathrm{m}^{2}$. Stem height, leaf area, fresh weight of aboveground part and dry weight of aboveground part of soybean were measured at 28 days after planting. The results showed that the increase of number of four weeds resulted in the increase of inhibition of all growth performance in soybean. The planting of soybean interfered with the weeds for 16 plants $/ \mathrm{m}^{2}$ exhibited that the maximum of inhibitory degree (52.61\%) followed by the planting of soybean interfered with the weeds for 128 and 4 plants $/ \mathrm{m}^{2}$ by $40.04,25.94$ and $13.08 \%$, respectively. The planting of soybean interfered with spiny amaranth $(A$. spinosus) exhibited that the highest of inhibitory degree $(35.41 \%)$, followed by the planting of soybean interfered with eclipta (E. prostrata), wild poinsettia (E. heterophylla) and slender amaranth $(A$. viridis) showed the inhibitory degree for $34.35,31.65$ and $30.27 \%$, respectively. This result presented the effects of density of weeds against soybean on growth parameters (stem height, leaf area, fresh weight of aboveground part and dry weight of aboveground part) as well as suggested that the planting of soybean should be the planting of soybean were not interfered with different weed density in order to the minimization of weed competition as well as the optimum method for weed arrangement.
\end{abstract}

Keywords: Weed interference, Growth performances, Soybean (Glycine max), Weed competition, Weed Density, Types of Weed

\section{Introduction}

Soybean (Glycine max L. Merr.) is the economic legume crop for three issues of utilization included food of human (Matsuo et al., 2018) feed for animal (Ferdous et al., 2017) and industrial application (Korres et al., 2020) and soybean contains abundant of protein and oil content (Das et al., 2014) and richs of mineral nutrients and vitamins (Matsuo et al., 2018). Soybean is the most important of legume crops, seeds of soybean comprise three groups of biochemical substance namely protein $(36 \%)$ carbohydrate $(30 \%)$ and oils (20\%) (Ferdous et al., 2017). Seeds of soybean were applied more than $50 \%$ of the total production of legume crops as oil crops application in the world (Matsuo et al., 2018).

Weeds is the economic pest of the agricultural fields and soybean cultivation as well as weeds showed the competition and interfered with the economic crops planting and soybean cultivation for three factor competition (water light and nutrition) for growth and development (Reis and Vivain, 2011). Shrestha et al. (2010) summarized that the disadvantage of weed infestation against the crops planting because the potential of the weed competition minimized of some factors (water, light and nutrition) on growth and yield of the crops planting.

The accumulation of the weed density in crop planting showed the growth retardation as well as the minimization of yield is more harmful than the reduction of the weed density (Agostinetto et al., 2017). For the soybean planting and economic field crops interfered with weeds competition showed the injury of some characters of crops and soybean planting included reduction of the growth characters (Keramati et al., 2008), damage of the yield components (Du et al., 2019) and decrease of the yields (Korres et al., 2020).

Weed interference exhibited that the damage of the growth character, minimization of the yield components and decrese of the yields charaters of the economic crops (Chauhan, 2011) For examples, Dhaker et al. (2010) inferred that the damage of the yield components and yield characters (pod length, 

and Types of Weed

pod weight and seed yield) of soybean (G. max) planting resulted from the weed interference namely Trianathema portulacastrum, Commelina benghalensis, Amaranthus spinosus, Digera arvensis and Parthanium hysterophorus. Jeschke et al. (2011) concluded that the yield loss of soybean (G. max) caused by the competition of two weed inferference namely giant foxtail (Setaria faberi) and yellow foxtail (Setaria pumila). Kavurmaci et al. (2010) predicated that the growth loss and yield damage in term of plant height, number of pods per plant, number of seeds per pod, seed weight and seed yield against faba bean (Vicia faba) resulted from weed competition namely avena sterilis, Lolium multiflorum, Chenopodium album, Amaranthus retroflexus, Convolvulus arvensis and Sinapsis arvensis. Vollmann et al. (2010) summarized that the weed infestation treatments noted that the grain yield loss of soybean $(G . \max$ ) is more destroyed than the weed free control. Bukun (2011) aggregated that the number of red root pigweed (Amaranthus retroflexus) for 5 plants $/ \mathrm{m}^{2}$ showed the maximum of the yield loss percentages against peanut (Arachis hypogoea) for $70 \%$, while the number of red root pigweed $(A$. retroflexus) for 1 plants $/ \mathrm{m}^{2}$ exhibited the minimum of the yield loss percentages against peanut (A. hypogoea) for $25 \%$. Jordan et al. (2009) comprehended that the peanut (A. hypogoea) cultivation interfered with some weed (eclipta (Eclipta prostrata) exhibited that the loss of growth characters is more injured than the control treatment (no weed competition).

Belel et al. (2011) abstracted that the weed competition treatment for 24 and 6 weeks after planting against sweet pepper (Capsicum aпnиит) showed the damage of the growth and yield component (fruit length, fruit diameter and fruit yield) is more destroyed than the weed free duration (no weed competition). Omoigui et al. (2012) noted that the weed infestation treatments (Striga gesnerioides and Alectra vogeli) against cowpea (Vigna unguiculata) showed the damage of growth and yield in term of pod per plant, seed weight and seed yield is more devastating than the control treatment (no weed infestation). Galon et al. (2016) comprehended that the number of weed competition (Bidens pilosa) of 60 plants $/ \mathrm{m}^{2}$ showed the highest of the productivity loss percentages against black bean (Phaseolus vulgaris) for $45 \%$, while the number of weed competition (B. pilosa) of 10 plants $/ \mathrm{m}^{2}$ presented that the lowest of the productivity loss percentages against black bean (P. vulgaris) for $30 \%$ as well as the control treatment (without infestation of weed) showed the productivity loss percentages against black bean for $0 \%$.

Besides, Du et al. (2019) inferred that the effect of the number of purple nutsedge (Cyperus rotundus) against peanut (A. hypogoea), the mumber of purple nutsedge (C. rotundus) of $150 \mathrm{plants} / \mathrm{m}^{2}$ showed the minimum of peanut yield for $1.2 \mathrm{ton} / \mathrm{ha}^{-1}$, while the mumber of purple nutsedge $(C$. rotundus $)$ of 10 plants $/ \mathrm{m}^{2}$ showed the maximum of peanut yield for $2.6 \mathrm{ton} / \mathrm{ha}^{-1}$ and the increase of the number of weed infestation resulted in the reduction of the peanut seed yield.

In the same way, Peer et al. (2013) noted that the weed infestation of soybean cultivation minimized on the growth of soybean and reduced on yield of soybean compared with the control treatment (no weed infestation). Besides, Korres et al. (2020) exhibited that the weed infestation treatments (soybean planting interfered with Amaranthus palmeri showed the seed yield loss of soybean $(G$. max) is more shabby than the weed free control (soybean planting without infestation of A.palmeri).

An inadequate data and incomplete information of the detriment of the growth charateristics (stem height, leaf area, fresh weight of aboveground part and dry weight of aboveground part) of soybean ( $G$. max) resulted from weed interference for four weeds namely wild poinsettia (E. heterophylla), eclipta $(E$. prostrata), slender amaranth (A. viridis) and spiny amaranth (A. spinosus).

The objective of this research was to study of the weed interference for four weeds namely wild poinsettia (E. heterophylla), eclipta (E. prostrata), slender amaranth (A. viridis) and spiny amaranth $(A$. spinosus) against soybean (G. max). It is predicated that the data may help to selection the weed species as the aggressive weed at the first time for weed management in soybean planting, consequence the selection the weed species as the non-aggressive weed at the second time for weed management in soybean planting.

\section{Materials and Methods \\ 2.1 Location}

This experiment was conducted at Department of Applied Science, Faculty of Science and Technology, Phranakhon $\mathrm{Si}$ Ayutthaya Rajabhat University, Phranakhon Si Ayutthaya province $\left(14^{\circ} 21^{\prime} \mathrm{N}\right.$, $\left.100^{\circ} 34^{\prime} \mathrm{E}\right)$, Thailand during 2018-2020.

\subsection{The tested plants and samples}

The soybean seeds were tested in this experiments as the local variety (Chiang mai 2 variety). The four weed species in this study namely wild poinsettia $(E$. heterophylla), eclipta (E. prostrata), slender amaranth (A. viridis) and spiny amaranth (A. spinosus) were collected from the Agricultural fields for three locations (Bangban, Wangnoi, and Uthai) 
Weed Interference and Growth Performances in Soybean (Glycine max (L.) Merr.), as affected by Weed Density and Types of Weed

in Phranakhon Si Ayutthaya Province $\left(14^{\circ} 21^{\prime} \mathrm{N}\right.$,

The data of four weed species are shown in Table 1. $\left.100^{\circ} 34^{\prime} \mathrm{E}\right)$, Thailand, during January-May, in 2018.

Table 1 The data of Family, scientific name, types of weeds and the score of loss to soybean cultivation of each weed.

\begin{tabular}{lllll}
\hline Weeds & Family & Scientific name & Types of weeds & $\begin{array}{l}\text { The score of loss to } \\
\text { soybean cultivation }\end{array}$ \\
\hline Wildpoinsettia & Euphorbiaceae & Euphorbia heterophylla & Broad leaf weed & Medium score \\
Eclipta & Asteraceae & Eclipta prostrata & Broad leaf weed & High score \\
Slender amaranth & Amaranthaceae & Amaranthus viridis & Broad leaf weed & Medium score \\
Spiny amaranth & Amaranthaceae & Amaranthus spinosus & Broad leaf weed & High score \\
\hline
\end{tabular}

\subsection{The experimental design}

The experimental design was $4 \times 5$ Factorial in CRD (Completely randomized design) with four replications. Factor A as type of weed spicies divided into four treatments (wild poinsettia (E. heterophylla), eclipta (E. prostrata), slender amaranth (A. viridis) and spiny amaranth (A. spinosus)) as well as Factor B as the density of weed interference on soybean planting, the treatment devided in to five treatments namely $\mathrm{T} 1$ control treatment (no weed interfered with soybean planting; the number for 0 plants $/ \mathrm{m}^{2}$ interfered with soybean planting) $\mathrm{T} 2$ the number for 4 plants $/ \mathrm{m}^{2}$ interfered with soybean planting T3 the number for 8 plants $/ \mathrm{m}^{2}$ interfered with soybean planting $\mathrm{T} 4$ the number for 12 plants $/ \mathrm{m}^{2}$ interfered with soybean planting and T5 the number for 16 plants $/ \mathrm{m}^{2}$ interfered with soybean planting.

The soybean planting were planted in plastic bags $(10 \times 20 \mathrm{~cm})$ then transplanted to the plant plot for $1 \times 1$ $\mathrm{m}^{2}$. The growth parameters of soybean (stem height, leaf area, fresh weight of aboveground part and dry weight of aboveground part) were measured at $28^{\text {th }}$ days after planting. The control treatment (no weed interfered with soybean planting) were tested of the number for 0 plants $/ \mathrm{m}^{2}$ interfered with soybean planting. The other soybean planting were interfered with four weeds namely wild poinsettia (E. heterophylla), eclipta (E. prostrata), slender amaranth (A. viridis) and spiny amaranth $(A$. spinosus) at different density for 4812 and 16 plants $/ \mathrm{m}^{2}$.

\subsection{The soybean growth evaluation}

The soybean growth evaluation were recorded at 28 days after planting for four characters namely stem height, leaf area, fresh weight of aboveground part and dry weight of aboveground part. For the stem height test, the plant height were measured from the base of the stem to the apex of the stem at 28 days after planting.

The leaf area character were measured at 28 days after planting for two types character of this leaves included leaf width and length length and calculated for leaf area $\left(\mathrm{LA} ; \mathrm{cm}^{2}\right)$ from the formula as follows ; $\mathrm{LA}=(\mathrm{AxB})$

Where $\mathrm{A}$ is the data of leaf width $(\mathrm{cm}$.) were measured from the leaf margin one side to the leaf margin other side and B is the data of leaf length $(\mathrm{cm}$.$) were measured from the leaf base to the leaf$ apex.

The growth performances in term of fresh weight of aboveground part and dry weight of aboveground part were measured at 28 days after planting and tested followed by the methods of AOSA (2002).

The soybean growth performances were measured at 28 days after planting for four charaters (stem height, leaf area, fresh weight of aboveground part and dry weight of aboveground part) were taken on the growth inhibition (M) with respect to the control treament (no weed interfered with soybean planting) was calculated from the formula as follows;

$\mathrm{M}=[(\mathrm{A}-\mathrm{B}) / \mathrm{A}] \mathrm{x} 100$

Where $\mathrm{A}$ is the growth parameters (stem height, leaf area, fresh weight of aboveground part and dry weight of aboveground part) of the control treament (no weed interfered with soybean planting) and B is the growth parameters (stem height, leaf area, fresh weight of aboveground part and dry weight of aboveground part) of the treatments were interfered with the four weeds at different density for 4812 and 16 plants/ $\mathrm{m}^{2}$ namely wild poinsettia $(E$. heterophylla), eclipta (E. prostrata), slender amaranth (A. viridis) and spiny amaranth (A. spinosus).

\subsection{Statistical analysis}

All experiments were tested for four replications. Data of four characteristics (inhibition of stem height, inhibition of leaf area, inhibition of fresh weight of aboveground part and inhibition of dry weight of aboveground part of soybean were measured at $28^{\text {th }}$ days after planting) were subjected to analysis using Duncan's Multiple Range Tests (DMRT).

\section{Results and discussion}

3.1 Impaction of density of wild poinsettia $(E$. heterophylla) on growth performances against soybean

The density of wild poinsettia (E. heterophylla) at different treatments showed the inhibition of stem height, leaf area, fresh weight of aboveground part and dry weight of aboveground part ranged from $22.36 \%$ to $62.34 \%$ inhibition. The density of wild poinsettia for 4 plants $/ \mathrm{m}^{2}$ demonstrated that the 
lowest of inhibition of stem hight character against soybean for $22.36 \%$ inhibition (Table 2 ). The density of wild poinsettia for 16 plants $/ \mathrm{m}^{2}$ noted that the peakest of inhibition of stem hight character against soybean for $62.34 \%$ inhibition. The density of wild poinsettia for 8 and 12 plants $/ \mathrm{m}^{2}$ against soybean exhibited that the degree of inhibition of stem height for 31.06 and $45.69 \%$ inhibition, respectively (Table $2)$. The data of the damage of the stem height charater against soybean caused by wild poinsettia competition exhibited inconformity with the researchs of Mishra et al. (2003) who found that the the decrease of the growth performance of soybean resulted from the Euphorbia sp. interference condidion as well as Adeluis et al. (2006) who showed tha the damage of the growth performance in term of stem hight of soybean caused by the wild poinsettia competition.

For the effect of the density of different of wild poinsettia populations (4 812 and 16 plants $/ \mathrm{m}^{2}$ ) on leaf area character against soybean, the density for 16 plants $/ \mathrm{m}^{2}$ presented that the maximum of inhibition (49.13\% inhibition) followed by 128 and 4 plants $/ \mathrm{m}^{2}$ of 41.1224 .64 and $10.63 \%$ inhibition, respectively (Table 2). These data showed inconformity with the finding of Lamptey et al. (2014) who found that the injury of the growth performance in case of leaf area against soybean caused by weed competition.

The density of wild poinsettia (E. heterophylla) at 48 12 and 16 plants $/ \mathrm{m}^{2}$ exhibited that the inhibition of fresh of aboveground part against soybean ranged from $10.25 \%$ to $30.69 \%$ inhibition. The density at 16 plants $/ \mathrm{m}^{2}$ demonstrated that the highest of inhibition (30.69\% inhibition) followed by 12 and 8 plants $/ \mathrm{m}^{2}$ for 21.24 and $16.78 \%$ inhibition, respectively as well as the density at 4 plants $/ \mathrm{m}^{2}$ presented that the lowest of inhibition (10.25\% inhibition) (Table 2). The data of the damage of fresh weight of aboveground part against soybean interfered with wild poinsettia competition that agreement with the resrarchs of Fickett et al. (2013) who showed that the damage of the growth parameters of soybean interfered with common lambsquarters (Chenopodium album) condition as well as Silva et al. (2014) who repoted that the derogation of the growth parameters of soybean in case of dry mass of stem and dry mass of leaves interfered with hairy fleabane infestation.

For the dry weight of aboveground part against soybean that interfered with different of wild poinsettia populations (4 812 and 16 plants $/ \mathrm{m}^{2}$ ), the inhibition of dry weight of aboveground part of soybean noted that the highest of inhibitory degree for $51.39 \%$ interfered with 16 plants $/ \mathrm{m}^{2}$, followed by the interfered with the density of wild poinsettia for 128 and 4 plants $/ \mathrm{m}^{2}$ by 43.6731 .28 and $14.25 \%$ inhibition, respectively (Table 2). This data showed that the inconformity with the other researchs of Rezvani et al. (2012) who exhibited that the damage of the growth character against soybean planting resulted from the increasing of the weed competition of soybean planting. Trezzi et al. (2013) who reported that the harm of growth character in case of dry matter of leaves and dry matter of stems against soybean caused by weed competition (horseweed; Conyza banariensis).

\subsection{Impaction of density of eclipta ( $E$. prostrata) on growth performances against soybean}

The density of eclipta ( $E$. prostrata) for 16 plants $/ \mathrm{m}^{2}$ showed that the highest of the inhibition on growth in term of stem height against soybean for $64.15 \%$ inhibition. The density of eclipta for 4 plants $/ \mathrm{m}^{2}$ exhibited that the lowest of inhibition of stem height against soybean by $9.76 \%$ inhibition (Table 3). The data of weed competition against soybean showed the injury of growth performance in term of stem height of soybean caused by eclipta $(E$. prostrata) infestation is agreement with the data of the researchs by Tyagi et al. (2011) who reported that the detriment of the growth character in case of stem hight against soybean resulted from weed competition as well as Ferdous et al. (2017) who noted that the loss of the growth performance in term of plant height caused by eclipta ( $E$. prostrata) competition of soybean planting.

The density of eclipta for 16 plants $/ \mathrm{m}^{2}$ exhibited that the peakest of inhibition in term of leaf area against soybean $(52.37 \%$ inhibition). The population of eclipta for 4 plants $/ \mathrm{m}^{2}$ demonstrated that the lowest of inhibition in case of leaf area (9.76\% inhibition) against soybean (Table 3 ). These data presented that the weed competition of eclipta against soybean showed that inconformity with the working of Ferdous et al. (2017) and Tyagi et al. (2011).

The density of eclipta at different treatments affected that the growth parameter in term of fresh weight of above ground part against soybean, the population of eclipta for 16 plants $/ \mathrm{m}^{2}$ showed that the peakest of inhibition incase of fresh weight of aboveground part (49.68\% inhibition). The population of eclipta for 4 plants $/ \mathrm{m}^{2}$ exhibited that the lowest of inhibition (7.45\% inhibition) in case of fresh weight of above ground part against soybean (Table 3). These research predicated that the inconformity with the working of Hazra et al. (2011) as well as Ferdous et al. (2017) showed that the loss of the growth performance in term of fresh weight plants against soybean caused by weed competition.

For the loss of dry weight of above ground part against soybean interfered with different eclipta 

and Types of Weed

density, the density of eclipta for 16 plants $/ \mathrm{m}^{2}$ presented that the maximum of inhibition (54.67\% inhibition) followed by the density of eclipta by 12 and 8 plants $/ \mathrm{m}^{2}$ for 46.78 and $31.23 \%$ inhibition, respectively. The density of eclipta for 4 plants $/ \mathrm{m}^{2}$ exhibited that the lowest of inhibition (13.64\% inhibition) (Table 3). The data of growth inhibition of soybean caused by eclipta competition that corroborate the working of Ferdous et al. (2017) who showed that the eclipta infestation of soybean planting resulted in the loss of the growth performance in term of dry weight plants against soybean. Besides, Pagnoncelli et al. (2017) who showed that the impaction of the density of weed competition on some growth parameters (stem height, leaf area, fresh stem mass and dry stem mass) against soybean.

4.3 Impaction of density of slender amaranth ( $A$. viridis) on growth performances against soybean The population of slender amaranth (A. viridis) for 16 plants $/ \mathrm{m}^{2}$ showed that the highest of inhibition interm of stem hight $(74.52 \%$ inhibition) against soybean followed by the population of slender amaranth by 12 and 8 plants $/ \mathrm{m}^{2}$ for 51.12 and $34.75 \%$ inhibition, respectively. The population of slender amaranth by 4 plants $/ \mathrm{m}^{2}$ exhibited that the lowest of inhibition incase of stem height against soybean (Table 4). The data of the damage of growth parameter of soybean in case of stem height interfered with slender amaranth showed inconformity with the data of the weed competition against soybean of Imoloame (2014) who comprehended that the effect of the weed competition in soybean cultivation resulted in the loss of the growth character in term of plant height against soybean.

The density of slender amaranth (A. viridis) at different of density treatments showed the inhibition of leaf area character against soybean for 11.23$45.29 \%$ inhibition (Table 4 ). The density of slender amaranth for 16 plants $/ \mathrm{m}^{2}$ exhibited that the peakest of inhibition of leaf area against soybean for $45.29 \%$ inhibition. The density of slender amaranth for 4 plants $/ \mathrm{m}^{2}$ presented that the lowest of leaf area against by $11.23 \%$ inhibition. The raising of the population of slender amaranth resulted in the increase of inhibition of leaf area character against soybean. These data confirm the finding of the research by Pagnoncelli et al. (2017) who showed that the impaction of the density of morning glory infestation of soybean planting inhibited of some growth parameters in case of leaf area against soybean.

The increase of density of slender amaranth ( $A$. viridis) resulted in the increase of inhibitory degree of growth parameter in term of fresh weight of above ground part against soybean. The density of slender amaranth for 16 plants $/ \mathrm{m}^{2}$ showed that the maximum of the inhibition (35.69\% inhibition) (Table 4). The density of slender amaranth for 4 plants $/ \mathrm{m}^{2}$ noted that the lowest of the inhibition ( $8.96 \%$ inhibition). From these study, the results confirm the finding of Pagnoncelli et al. (2017) who concluded that the impaction of the density of morning glory infestation of soybean planting presented that the loss of some growth parameters in term of fresh stem mass and dry stem mass against soybean.

The population of slender amaranth at different density (4 812 and 16 plants $/ \mathrm{m}^{2}$ ) presented that the inhibition of growth character in case of dry weight of above ground part against soybean ranged from $13.26 \%$ to $49.96 \%$ inhibition (Table 4). The population of slender amaranth by 4 plants $/ \mathrm{m}^{2}$ showed that the lowest of inhibition (13.26\% inhibition), while the population of slender amaranth by 16 plants $/ \mathrm{m}^{2}$ exhibited that the highest of inhibition (49.96\% inhibition). The progressive of population of slender amaranth (A. viridis) affected that the increase of the inhibition of dry weight of above ground part against soybean. These data presented that the inconformity of the finding works of El-Gizawy et al. (2012) and Peer et al. (2013) who showed that the increase of the number of weed infestation in soybean cultivation resulted from the cumulative of the inhibition of growth of soybean as well as loss of the yield component and seed yield of soybean.

4.4 Impaction of density of spiny amaranth (A. spinosus) on growth performances against soybean The population of spiny amaranth (A. spinosus) for 16 plants $/ \mathrm{m}^{2}$ demonstrated that the highest of inhibition of stem hight against soybean for $81.45 \%$ ihhibition. The population of spiny amaranth by 4 plants $/ \mathrm{m}^{2}$ noted that the lowest of inhibition of stem height for $25.63 \%$ inhibition (Table 5). The increase of the density of spiny amaranth showed that the raising of inhibition of growth character incase of leaf area against soybean. The density of spiny amaranth by 4 plants $/ \mathrm{m}^{2}$ presented that the lowest of the inhibition (14.56\% inhibition), while the density of spiny amaranth by 16 plants $/ \mathrm{m}^{2}$ showed that the peakest of inhibition (47.18\% inhibition) (Table 5). These data from the study of spiny amaranth interfered with the soybean planting showed the incoformity with the finding by Aluko et al. (2012) and Amaregouda et al. (2013).

The raising of the population of spiny amaranth resulted in the increasing of the inhibition of two growth charaters in term of fresh weight aboveground part and dry weight aboveground part (Table 5). The population of spiny amaranth by 16 plants $/ \mathrm{m}^{2}$ showed 
that the highest of inhibition of fresh weight aboveground part and inhibition of dry weight aboveground part for 42.26 and $51.19 \%$ inhibition, respectively. while, the population of spiny amaranth by 4 plants $/ \mathrm{m}^{2}$ noted that the lowest of inhibition of fresh weight aboveground part and inhibition of dry weight aboveground part for 6.96 and $17.84 \%$ inhibition, respectively. The data from the study showed the agreement with the finding works of Ferdous et al. (2017).

4.5 The effects of different density of four weed species interfered with soybean planting on growth performance against soybean

The cumulative of the population of four weed species (wild poinsettia (E. heterophylla), eclipta (E. prostrata), slender amaranth (A. viridis) and spiny amaranth (A. spinosus)) showed that the increase of the inhibitory degree on growth performances (stem height, leaf area, fresh weight aboveground part and dry weight aboveground part) against soybean (Table $6)$.

The population of the weed competition for 16 plants $/ \mathrm{m}^{2}$ noted that the peakest of the inhibition of growth performance for $52.41 \%$ inhibition against soybean, followed by the population of weed competition by 12 and 8 plants $/ \mathrm{m}^{2}$ for 40.04 and $25.94 \%$ inhibition, respectively. The population of weed competition for 4 plants $/ \mathrm{m}^{2}$ demonstrated that the lowest of the inhibition of growth character by $13.08 \%$ inhibition against soybean.

The data from these research showed the increase of population of the weed competition noted that the increase of the injury of growth performances against soybean. It is agreement with the finding works of Rezvani et al. (2012), Aluko et al. (2012) as well as Peer et al. (2013) who demonstrated that the weed infestation of soybean cultivation showed the loss of growth and yield against soybean is more ricketly than the weed free treatment. Besides, Amaregouda et al. (2013) who described that the soybean planting interfered with weed competition showed the loss of growth and yield characters in case of leaf area, total drymatter, pod weight and seed yield against soybean is more destroyed than the control treatment (weed free treatment).

In addition, the different types of the weeds for testing showed the different degree of the inhibition for weed interference against soybean planting. The spiny amaranth (A. spinosus) interfered with soybean planting exhibited that the highest of inhibitory degree for $35.41 \%$ inhibition, followed by the eclipta (E. prostrata) and wild poinsettia (E. heterophylla) for 34.35 and $31.65 \%$ inhibition, respectively. The slender amaranth $(A$. viridis) interfered with soybean planting showed the lowest of inhibitory degree for $30.27 \%$ inhibition (Table 6). These results showed that the difference of weed species infestation resulted in the difference of the damage of growth performances against soybean. The spiny amaranth (A. spinosus) competition showed the highest of the damage of growth performances against soybean, while the slender amaranth $(A$. viridis) competition showed the lowest of the damage of growth performances against soybean.

The data from these study demonstrated that inconformity with the researchs of Ferdous et al. (2017) who showed that the different of types weed species in soybean planting resulted in the loss of the growth against soybean ranged from 14.25-72.19\%, the Echinochloa colona competition of soybean planting showed the highest of the loss of growth by $72.19 \%$, followed by the Lindermia procumbens competition $(28.28 \%)$ and the Cynodon dactylon competition of soybean planting showed the lowest of the loss of growth by $14.25 \%$. as well as Tyagi et al. (2011) who found that the difference of types weeds competition showed the disadvantage of growth and yield against soybean, the Cyperus rotundus competition of soybean planting exhibited the loss of growth and yield against soybean is more ruined than the Dactyloctenium aegyptium competition of soybean planting. Besides, El-Gizawy et al. (2012) who inferred that the difference of types of weeds competition (Xanthium brasilicum, Portulaca oleracea and Amaranthus ascendes) showed the difference of the loss of growth and yield against soybean.

The population of weed competition for 16 plants $/ \mathrm{m}^{2}$ noted that the maximum of the damage of the growth performances against soybean cultivation. The population of weed competition for 16 plants $/ \mathrm{m}^{2}$ affected to the loss of growth performances against soybean because the weed competition presented the growth retardation in case of stem height, leaf area, fresh weight aboveground part and dry weight aboveground part (Silva et al., 2014) as well as the weed interference (16 128 and 4 plants $/ \mathrm{m}^{2}$ ) showed the competition between soybean and some weeds for three factors (water light and nutrition) are more destroyed than the control treatment (weed competition for 0 plants $/ \mathrm{m}^{2}$ ).

The population of weed competition as high levels competition treatment $\left(16\right.$ plants $\left./ \mathrm{m}^{2}\right)$ presented that the maximum of the inhibition (52.61\% inhibition) of growth characters against soybean planting, while the population of weed competition as low levels competition treatment (4 plants $/ \mathrm{m}^{2}$ ) exhibited that the minimum of the inhibition (13.08\% inhibition) of growth characters against soybean planting (Table 6). 

and Types of Weed

From these study, the population of weed competition as high levels competition treatment (16 plants $/ \mathrm{m}^{2}$ ) showed the loss of growth performances against soybean is more disruptive than the population of weed competition as low levels competition treatment $\left(4\right.$ plants $\left./ \mathrm{m}^{2}\right)$. The results corroborate that the researchs of Das et al. (2014) who aggregated that the weed interference of soybean planting by 2550100150 and 200 plants $/ \mathrm{m}^{2}$ showed the loss of seed yield against soybean by $10-41 \%$, the weed interference of soybean planting by 200 plants $/ \mathrm{m}^{2}$ exhibited that the peakest of the loss of seed yield for $41 \%$, while the weed interference of soybean planting by 25 plants $/ \mathrm{m}^{2}$ presented that the lowest of the loss of seed yield for $10 \%$.

Furthermores, Du et al. (2019) who discovered that the weed interference of peanut planting by 102040 80120 and 160 plants $/ \mathrm{m}^{2}$ showed the loss of seed yield against peanut ranged from $4 \%$ to $49 \%$, the weed interference of peanut planting by 160 plants $/ \mathrm{m}^{2}$ displayed that the highest of the loss of seed yield for $49 \%$, while the weed interference of peanut planting by 10 plants $/ \mathrm{m}^{2}$ revealed that the lowest of the loss of seed yield for $4 \%$.

The weed competition showed the damage of the growth performances against soybean that inconformity with the researchs of Hazra et al. (2011) who noted that the horse purslane (Trianthema portulacastrum) competition of soybean cultivation resulted in the loss of growth and yield against soybean is more destructive thant the control treatment (no weed competition) as well as Trezzi et al. (2013) who showed that the horseweed (Conyza bonariensis) competition of soybean planting resulted in the loss of growth appearance incase of leaf area, branch per plant and dry matter of leaves against soybean is more dilapidated than the control treatment.

In the same way, Agostinetto et al. (2017) who reported that the soybean planting interfered with hairy fleabane infestation showed the loss of growth and yield against soybean is more harmful than the soybean planting alone (no weed interference).

The data from this research is the invaluable data of the weed interference study against soybean planting. The selection of the weed control as the highest of the inhibitory degree of some weed (aggrassive weed) at the first time in weed mananement included the spiny amaranth (A. spinosus) competition ( $35.41 \%$ inhibition), then the selection of the weed control as the lowest of the inhibitory degree of some weed (non-aggrassive weed) at the second time in weed management included the slender amaranth $(A$. viridis) competition (30.27\% inhibition).
These finding inferred that qualitative data of the weed interference for four weed species (wild poinsettia (E. hyterophylla), eclipta (E. prostrata), slender amaranth $(A$. viridis $)$ and spiny amaranth $(A$. spinosus) on some growth performances (stem height, leaf area, fresh weight of aboveground part and dry weight of aboveground part) of soybean.

It is the comprehensive information of weed interference in soybean cultivation as well as the applicatiom of the data of weed competition of these finding for selection method of the best control for weed management of soybean planting.

\section{Conclusion}

This research presented the effects of different density ( $\begin{array}{llll}0 & 4 & 8 & 12\end{array}$ and 16 plants $/ \mathrm{m}^{2}$ ) for four weed species (wild poinsettia (E. hyterophylla), eclipta $(E$. prostrata), slender amaranth (A. viridis) and spiny amaranth (A. spinosus)) on growth characteristics against soybean $(G$. max). The increase of number of four weeds resulted in the increase of inhibition of all growth performances (stem height, leaf area, fresh weight of aboveground part and dry weight of aboveground part) against soybean.

The planting of soybean interfered with the weeds for 16 plants $/ \mathrm{m}^{2}$ exhibited that the maximum of inhibitory degree $(52.61 \%)$ followed by the planting of soybean interfered with the weeds at 128 and 4 plants $/ \mathrm{m}^{2}$ for $40.04,25.94$ and $13.08 \%$, respectively. The data of the damage of the the growth performance against soybean planting showed the difference of inhibitory degree depending on the type of weed species. The planting of soybean interfered with spiny amaranth (A. spinosus)) exhibited that the highest of inhibitory degree $(35.41 \%)$, followed by the planting of soybean interfered with eclipta $(E$. prostrata), wild poinsettia (E. hyterophylla) and slender amaranth (A. viridis) demonstrated the inhibitory degree for $34.35,31.65$ and $30.27 \%$, respectively.

This result presented the effects of density of weeds against soybean on growth parameters (stem height, leaf area, fresh weight of aboveground part and dry weight of aboveground part) as well as suggested that planting of soybean should be the planting of soybean were not interfered with different weed density in order to weed arrangement.

These finding showed that comprehensive data of the weed interference of four weed species (wild poinsettia (E. hyterophylla), eclipta (E. prostrata), slender amaranth (A. viridis) and spiny amaranth $(A$. spinosus) on growth characteristics against soybean (G. max). It is the newest information as weed competition in soybean planting had exploited for the 

and Types of Weed

optimum selection method of the best control for weed administration.

\section{References}

1. Adeluis, A. A., G. T. Odufeko and A. M. Makinde. 2006. Interference of Euphorbia heterophylla L. on the growth and reproductive yield of soybean (Glycine max (L.) Merill. Res. J. Bot. 1: 85-94.

2. Agostinetto, D., D. R. O. Silva and L. Vargas. 2017. Soybean yield loss and economic thresholds due to ghyphosate resistant hairy fleabane interference. Arq. Inst. Biol. 84 :1-8.

3. Aluko, O. A., D. Chikoye and M. A. K. Smith. 2012. Effects of tillage plant spacing and soybean genotypes on speargass (Imperata cylindrica L.) reauschel suppression. Afr. J. Agric. Res. 7 :1068-1072.

4. Amaregouda, A., J. Jadhav., M. B. Chetti and Nawalagatti. 2013. Effect of weedicides on physiological parameters growth and yield components of soybean (Glycine max L.) and weed growth. Journal of Agriculture and Allied Sciences. $2: 12-15$

5. AOSA. 2002. Seed Vigor Testing Handbook. Association of Official Seed Analysts. No.32.

6. Belel, M. D., M. S. Saidu and A. A. Sajo. 2011. Effect of land preparation and weeding regime on the yield of sweet pepper (Capsicum апnиum L.) in Mubi, Adamawa State. Journal of Agronomy. 10 :62-67.

7. Bukun, B. 2011. Influence of redroot pigweed (Amaranthus retroflexus) density and biomass om peanut (Arachis hypogoea) yield. Afr. J. Biotechnol. 10 :19542-19546.

8. Chauhan, B. S. 2011. Crownfootgrass (Dactyloctenium aegyptium) germination and response to herbicides in Philippines. Weed Science. 59: 512-516.

9. Das, T. K., A. K. Paul and N. T. Yaduraju. 2014. Densityeffect and economic threshold of purple nutsedge (Cyperus rotundus) in soybean. J. Pest Sci. 87:211-220.

10. Dhaker, S. C., S. L. Mundra and V. Nepalia. 2010. Effect of weed management and sulphur nutrition on productivity of soybean (Glycine $\max$ (L.) Merrill). Indian J. Weed Sci. $42: 232-234$

11. Du, L., X. Li., J. Chen., X. Jiang., Q. Ju., C. Qu and M. Qu. 2019. Density effect and economic threshold of purple nutsedge (Cyperus rotundus L.) in peanut (Arachis hypogaea L.). International Journal of Plant Peoduction. 13:309-316.

12. El-Gizawy., N. K. B., A. M. Fadlallah., A. M. Hassanein and I. E. Soliman. 2012. Estimation of the critical period for weed control in soybean (Glycine $\max$ L.) as influenced by plant density. J. Plant Production. 3 :2375-2394.

13. Ferdous, J., M. H. Ali., M. S. Islam., I. F. Chowdhury., M. N. Haque and S. M. masum. 2017. Growth and yield of soybean as affected by irrigation and weed control methods. Bangladesh J. Weed Sci. 6 :17-26.

14. Fickett, N. D., C. M. Boerboom and D. E. Stoltenberg. 2013. Soybean yield loss potential associated with early-season weed competition across 64 site-years. Weed Science. $61: 500-507$.

15. Galon, L., C. T. Forte., R. L. Gabiatti., L. L. Radunz., I. Aspiazu., R. Kujawinski., F. A. David., C. T. Castoldi., G. F. Perin., A. L. Radunz and J. Rossetti. 2016. Interference and economic threshold level for control of beggartick on bean cultivars. Planta Daninha, Vicosa-Mg. 34 :411-422.

16. Hazra, D., T. K. Das and N. T. Yaduraju. 2011. Interference and economic threshold of horse purslane (Trianthema portulacastrum) in soybean cultivation in Northern India. Weed Biology and Management. 11 :72-82.

17. Imoloame, E. O. 2014. The effects of different weed control methods on weed infestation growth and yield of soybean (Glycine $\max (\mathrm{L}$.) Merril) in the Southern Guinea Savanna of Nigeria. Agrosearch. 14 :1299-143.
18. Jeschke, M. R., D. E. Stoltenberg., G. O. Kegode and C. L. Sprague. 2011. Predicted soybean yield loss as affected by emegence time of mixed species weed communities. Weed Science. $59: 416-423$.

19. Jordan, D. L., S. H. Lancaster., J. E. Lanier., B. R. Lassiter and P. D. Johnson. 2009. Peanut and eclipta (Eclipta prostrata) response to flumioxazin. Weed Technology. 23 231-235.

20. Kavurmaci, Z., U. Karadavut., K. Kokten and A. Bakoglu. 2010. Determining critical period of weed-crop competition in faba bean (Vicia faba). Int. J. Agric. Biol. 12 :318-320.

21. Keramati, S., H. Pirdashti., M. A. Esmaili., A. Abbasian and M. Habibi. 2008. The critical period of weed control in soybean (Glycine max (L.) Merr.) in North of Iran conditions. Pak. J. Biol. Sci. 11:463-467.

22. Korres, N. K., J. K. Norsworthy., A. Mauromoustakos and M. M. Williams. 2020. Soybean density and palmer amaranth (Amaranthus palmeri) establishment time : effects on weed biology crop yield and economic returns. Weed Science. 41:1-9.

23. Lamptey, S., S. Yeboah., K. Sakodie and A. Berdjour. 2014 Growth and yield pesponse of soybean under different weeding regimes. Asian Journal of Agriculture and Food Sciences. 3:155-163

24. Matsuo, N., T. Yamada., Y. Takada., K. Furami and M. Hajika. 2018. Effect of plant density on growth and yield of new soybean genotypes grown under early planting condition in Southwestern Japan. Plant Production Science. 21:16-25.

25. Mishra, J. S. and V. P. Singh. 2003. Interference of Euphorbia geniculata in soybean-chickpea cropping system. Ind. J. Weed Sci. 35: 225-227.

26. Omoigui, L. O., A. Y. Kamara., M. F. Ishiyaku and O Boukar. 2012. Comparative responses of cowpea breeding lines to Striga and Alectra in the dry savanna of Northeast Nigeria. Afr. J. Agric. Res. 7:747-754.

27. Pagnoncelli, F. D. B., M. Trezzi., B. Brun and R. A. Vidal. 2017. Morning glory species interference on the development and yield of soybean. Bragatia. 76:1-11.

28. Peer, F. A., B. Hassan., B. A. Lone., S. Quyoom., L. Ahmed. B. A. Khanday., P. Ssingh and G. Singh. 2013. Effect of weed control methods on yield and yield attributes of soybean. African Journal of Agrcultural Research. 8:61356141.

29. Reis, A. R. and R. Vivian. 2011. Weed competition in the soybean crop management in Brazil. p. 185-210. In SoybeanApplications and Technology. Brazil.

30. Rezvani, M., M. Ahangari and F. Zaefarian. 2012. Effect of cultivar and weeding regimes on soybean yields. World Academy of Science, Engineering and Technology. 69: 509. 511.

31. Shrestha, A., B. D. Hanson., M. W. Fidelibus and M. Alcorta 2010. Growth phenology and intraspecific competition between glyphosate-resistant and glyphosate-susceptible horseweeds (Conyza canadensis) in the San Jaoquin of California. Weed Science. 58:147-153.

32. Silva, D. R. S., L. Vargas., D. Agostinetto and F. Mariani. 2014. Glyphosate-resistant hairy fleabane competition in RR soybean. Bragantia, Campinas. 73:451-457.

33. Trezzi, M. M., J. A. A. Balbinot., G. Benin., F. Debastani., F. Patel and J. E. Miotto. 2013. Competitive ability of soybean cultivars with horseweed (Conyza banariensis). Planta Daninha, Viscosa-MG. 31:543.550

34. Tyagi, P. K., S. P. Singh and T. S. Dudwe. 2011. Weed flora of soybean (Glycine max (L.) Merrill) in different blocks of Tikamgarh district of Madhya Pradesh. The Journal of Rural and Agricultural Research. 11: 28-30.

35. Vollmann, J., H. Wagentristl and W. Hartl. 2010. The effects of simulated weed pressure on early maturity soybean. European Journal of Agronomy. 32:243-248. 
Weed Interference and Growth Performances in Soybean (Glycine max (L.) Merr.), as affected by Weed Density and Types of Weed

Table 2 Inhibitory percentage of stem height, leaf area, fresh weight and dry weight of aboveground part in soybean interfered with different density of wild poinsettia (E. heterophylla)

\begin{tabular}{lcccc}
\hline $\begin{array}{l}\text { Treatments (plants/ } \\
\mathrm{m}^{2} \text { ) }\end{array}$ & \multicolumn{4}{c}{ Inhibitory percentage (\%) } \\
\cline { 2 - 5 } & Stem height & Leaf area & $\begin{array}{c}\text { Fresh weight of } \\
\text { aboveground part }\end{array}$ & $\begin{array}{c}\text { Dry weight of } \\
\text { aboveground part }\end{array}$ \\
\hline 4 & $22.36 \mathrm{~d}$ & $10.63 \mathrm{~d}$ & $10.25 \mathrm{~d}$ & $14.25 \mathrm{~d}$ \\
8 & $31.06 \mathrm{c}$ & $24.64 \mathrm{c}$ & $31.28 \mathrm{c}$ & $43.67 \mathrm{~b}$ \\
12 & $45.69 \mathrm{~b}$ & $41.12 \mathrm{~b}$ & $21.24 \mathrm{~b}$ & $51.39 \mathrm{a}$ \\
16 & $62.34 \mathrm{a}$ & $49.13 \mathrm{a}$ & $30.69 \mathrm{a}$ & 8.15 \\
\hline C.V. $(\%)$ & 7.64 & 6.36 & 8.92 & \\
\hline
\end{tabular}

Values with different letter showed significant difference $(\mathrm{p}<0.05)$ as determined by Duncan 's Muntiple Range Test (DMRT).

Table 3 Inhibitory percentage of stem height, leaf area, fresh weight and dry weight of aboveground part in soybean interfered with different density of eclipta (E. prostrata)

\begin{tabular}{lcccc}
\hline $\begin{array}{l}\text { Treatments (plants/ } \\
\left.\mathrm{m}^{2}\right)\end{array}$ & \multicolumn{4}{c}{ Inhibitory percentage (\%) } \\
\cline { 2 - 5 } & Stem height & Leaf area & $\begin{array}{c}\text { Fresh weight of } \\
\text { aboveground part }\end{array}$ & $\begin{array}{c}\text { Dry weight of } \\
\text { aboveground part }\end{array}$ \\
\hline 4 & $9.76 \mathrm{~d}$ & $10.32 \mathrm{~d}$ & $7.45 \mathrm{~d}$ & $13.64 \mathrm{~d}$ \\
8 & $30.12 \mathrm{c}$ & $28.96 \mathrm{c}$ & $31.23 \mathrm{c}$ & $46.78 \mathrm{~b}$ \\
12 & $53.64 \mathrm{~b}$ & $43.64 \mathrm{~b}$ & $35.64 \mathrm{~b}$ & $54.67 \mathrm{a}$ \\
16 & $64.15 \mathrm{a}$ & $52.37 \mathrm{a}$ & $49.68 \mathrm{a}$ & 6.35 \\
\hline C.V. $(\%)$ & 9.63 & 7.94 & 6.74 & \\
\hline
\end{tabular}

Values with different letter showed significant difference $(\mathrm{p}<0.05)$ as determined by Duncan's Muntiple Range Test (DMRT).

Table 4 Inhibitory percentage Inhibition of stem height, leaf area, fresh weight and dry weight of aboveground part in soybean interfered with different density of slender amaranth (A. viridis)

\begin{tabular}{lcccc}
\hline $\begin{array}{l}\text { Treatments (plants/ } \\
\mathrm{m}^{2} \text { ) }\end{array}$ & \multicolumn{4}{c}{ Inhibitory percentage (\%) } \\
\cline { 2 - 5 } & Stem height & Leaf area & $\begin{array}{c}\text { Fresh weight of } \\
\text { aboveground part }\end{array}$ & $\begin{array}{c}\text { Dry weight of } \\
\text { aboveground part }\end{array}$ \\
\hline 4 & $12.54 \mathrm{~d}$ & $11.23 \mathrm{~d}$ & $8.96 \mathrm{~d}$ & $13.26 \mathrm{~d}$ \\
8 & $34.75 \mathrm{c}$ & $19.26 \mathrm{c}$ & $21.54 \mathrm{c}$ & $31.62 \mathrm{~b}$ \\
12 & $51.12 \mathrm{~b}$ & $31.25 \mathrm{~b}$ & $24.56 \mathrm{~b}$ & $49.96 \mathrm{a}$ \\
16 & $74.52 \mathrm{a}$ & $45.29 \mathrm{a}$ & $35.69 \mathrm{a}$ & 9.24 \\
\hline C.V. $(\%)$ & 8.96 & 7.45 & 10.21 & \\
\hline
\end{tabular}

Values with different letter showed significant difference $(\mathrm{p}<0.05)$ as determined by Duncan 's Muntiple Range Test (DMRT).

Table 5 Inhibitory percentage of stem height, leaf area, fresh weight and dry weight of aboveground part in soybean interfered with different density of spiny amaranth (A. spinosus)

\begin{tabular}{lcccc}
\hline $\begin{array}{l}\text { Treatments } \\
\left(\text { plants } / \mathrm{m}^{2}\right)\end{array}$ & \multicolumn{2}{c}{ Inhibitory percentage (\%) } \\
\cline { 2 - 5 } & Stem height & Leaf area & $\begin{array}{c}\text { Fresh weight of } \\
\text { aboveground part }\end{array}$ & $\begin{array}{c}\text { Dry weight of } \\
\text { aboveground part }\end{array}$ \\
\hline 4 & $25.63 \mathrm{~d}$ & $14.56 \mathrm{~d}$ & $6.96 \mathrm{~d}$ & $17.54 \mathrm{~d}$ \\
8 & $36.74 \mathrm{c}$ & $23.15 \mathrm{c}$ & $30.23 \mathrm{c}$ & $41.28 \mathrm{~b}$ \\
12 & $58.79 \mathrm{~b}$ & $39.65 \mathrm{~b}$ & $31.12 \mathrm{~b}$ & $51.19 \mathrm{a}$ \\
16 & $81.45 \mathrm{a}$ & $47.18 \mathrm{a}$ & $42.26 \mathrm{a}$ & 8.25 \\
\hline C.V. $(\%)$ & 7.89 & 10.23 & 6.98 & \\
\hline
\end{tabular}

Values with different letter showed significant difference $(\mathrm{p}<0.05)$ as determined by Duncan's Muntiple Range Test (DMRT).

Table 6 Mean of inhibitory percentage of growth characteristics in soybean interfered with different density of four weed species.

\begin{tabular}{|c|c|c|c|c|c|c|}
\hline \multirow{2}{*}{$\begin{array}{l}\text { Treatments } \\
\left(\text { plants } / \mathrm{m}^{2}\right)\end{array}$} & \multicolumn{6}{|c|}{ Type of weeds } \\
\hline & $\begin{array}{l}\text { Wild poinsettia } \\
(\text { E.heterophylla) }\end{array}$ & $\begin{array}{c}\text { Eclipta } \\
(\text { E.prostrata })\end{array}$ & $\begin{array}{l}\text { Slender } \\
\text { amaranth } \\
\text { viridis) }\end{array}$ & $(A$. & $\begin{array}{l}\text { Spinyamaranth } \\
\text { (A.spinosus) }\end{array}$ & Mean \\
\hline 4 & $14.37 \mathrm{~d}$ & $10.29 \mathrm{~d}$ & $11.48 \mathrm{~d}$ & & $16.17 \mathrm{~d}$ & $31.08 \mathrm{D}$ \\
\hline 8 & $25.94 \mathrm{c}$ & $26.98 \mathrm{c}$ & $23.60 \mathrm{c}$ & & $27.26 \mathrm{c}$ & $25.94 \mathrm{C}$ \\
\hline 12 & $37.93 b$ & $44.92 b$ & $34.63 b$ & & $42.71 b$ & $40.04 \mathrm{~B}$ \\
\hline 16 & $48.38 \mathrm{a}$ & $55.21 \mathrm{a}$ & $51.36 \mathrm{a}$ & & $55.52 \mathrm{a}$ & $52.61 \mathrm{~A}$ \\
\hline Mean & $31.65 \mathrm{~B}$ & $34.35 \mathrm{~A}$ & $30.27 \mathrm{~B}$ & & $35.41 \mathrm{~A}$ & 32.92 \\
\hline
\end{tabular}

Values with different letter showed significant difference $(\mathrm{p}<0.05)$ as determined by Duncan's Muntiple Range Test (DMRT). 